\title{
Üniversite Öğrencilerinin Finansal Okuryazarlık Düzeyleri Üzerine Bir İnceleme: Kahramanmaraş Sütçü İmam Üniversitesi Sosyal Bilimler Meslek Yüksekokulu Örneği ${ }^{1}$
}

\author{
Levent SEZAL \\ Dr. Öğr. Üyesi, Kahramanmaraş Sütçü İmam Üniversitesi, \\ Sosyal Bilimler Meslek Yüksekokulu, Yönetim ve Organizasyon Bölümü \\ leventsezal@ksu.edu.tr \\ Orcid ID: https://orcid.org/0000-0002-8873-7335
}

\begin{abstract}
$\ddot{\mathbf{O} z}$
Bireylerin gündelik hayatta karşısına çıkabilecek her türlü finansal problemlerin üstesinden gelebilmek için finans sistemi hakkında yeterli bilgi düzeyine sahip olması gerekmektedir. Bu bilgi düzeyi, finansal okuryazarlık olarak ifade edilmektedir ve finansal konularda etkin kararların alınmasında son derece önemli bir etkiye sahiptir. Bu çalışma ile üniversite öğrencilerinin finansal okuryazarlık düzeylerinin ölçülmesi ve bu düzeylerin demografik değişkenlere göre farklılıklarının analiz edilmesi amaçlanmaktadır. $\mathrm{Bu}$ kapsamda Kahramanmaraş Sütçü İmam Üniversitesi Sosyal Bilimler Meslek Yüksekokuluna kayıtlı 467 öğrenciye anket uygulanmıştır. Bulgulara göre; erkek öğrencilerin finansal okuryazarlık başarı puanlarının kadın öğrencilere kıyasla daha yüksek olduğu tespit edilmiştir. Ayrıca öğrencilerin yaşları arttıkça finansal okuryazarlık düzeyinin arttığı sonucuna varılmıştır. Finansal okuryazarlık düzeyi en yüksek bölüm Bankacılık ve Sigortacılık bölümü öğrenciler, olurken en düşük finansal okuryazarlık düzeyi ise Turizm ve Otel İşletmeciliği bölümü öğrencileri olmuştur. İnternet bankacılığı ve kredi kartı kullanım durumunun öğrencilerin finansal okuryazarlık düzeyleri üzerinde anlamlı bir farklılık olmadığı tespit edilmiştir.
\end{abstract}

Anahtar Kelimeler: Finans, Finansal Okuryazarl1k, Anova Testi.

\footnotetext{
${ }^{1}$ Makale Geliş/Kabul Tarihi: 03.05.2021/04.10.2021

Künye Bilgisi: Sezal, L. (2021). Üniversite öğrencilerinin finansal okuryazarlık düzeyleri üzerine bir inceleme: Kahramanmaraş Sütçü İmam Üniversitesi Sosyal Bilimler Meslek Yüksekokulu örneği. Kahramanmaraş Sütçü İmam Üniversitesi Sosyal Bilimler Dergisi, 18 (3), 2114-2137. DOI: 10.33437/ksusbd.932055.
} 


\title{
An Investigation on Financial Literacy Levels of University Students: Kahramanmaraş Sütçü İmam University Vocational School Of Social Sciences Sample
}

\begin{abstract}
Individuals must have sufficient knowledge about the financial system in order to overcome all kinds of financial problems that may arise in daily life. This level of knowledge is expressed as financial literacy and has an extremely important effect on making effective decisions on financial matters. The aim of this study is to measure the financial literacy levels of university students and analyze the differences of these levels according to demographic variables. In this context, a questionnaire was applied to 467 students enrolled in the Social Sciences Vocational School of Kahramanmaraş Sütçü İmam University. Answers given to the questionnaire were categorized into general success level and subheadings and success scores were determined. In the analysis of the data obtained as a result of the survey study, t-test and One-Way Analysis of Variance methods were used. According to the results of the research; It was determined that the financial literacy success scores of male students were higher than that of female students. In addition, it was concluded that as the age of the students increases, the level of financial literacy increases. The students of the Department of Banking and Insurance had the highest level of financial literacy, while the students of the Department of Tourism and Hotel Management had the lowest level of financial literacy. It has been determined that there is no significant difference between internet banking and credit card usage on the level of financial literacy.
\end{abstract}

Keywords: Finance, Financial Literacy, Anova Test.

\section{GİRIŞ}

İnternet ve iletişim teknolojilerinde ortaya çıkan gelişmeler, finansal ürün ve hizmetlerin sunumunu değişikliğe uğratmış, söz konusu ürün ve hizmetlere erişim daha ulaşlabilir hale gelmiştir. Bu durum, doğru finansal seçimler için tüketicilerin finansal okuryazarlığa sahip olması gereğini ortaya çıkarmıştır (Braunstein ve Welch, 2002: 446). Çünkü finansal okuryazarlık bireye piyasalara giriş konusunda daha yüksek bir yetkinlik düzeyi sağlamaktadır (Cole, Paulson ve Shastry, 2012: 15). Yüksek finansal okuryazarlık düzeyine sahip olan bireyler, daha kaliteli ürün ve hizmetleri talep etmekte; böylece finansal piyasalar daha etkin bir işleve sahip olmaktadır (Widdowson ve Hailwood, 2007: 40). Finansal okuryazarlık kişilerin girişimcilik niyetini pozitif yönlü olarak etkilemekte, girişimciliğin artmasına vesile olmaktadır (Dilek vd., 2019: 102). Finansal okuryazarlık düzeyi düşük olan bireyler ise hem kendilerini hem toplumu 
etkileyen kötü finansal kararlar alabilmektedir (Gale ve Levine, 2011: 4). Özellikle etkin olmayan para yönetimi, olumsuz finansal davranışların ortaya çıkmasına neden olabilmektedir (Braunstein ve Welch, 2002: 446).

Finansal okuryazarlığı, finansal risk ve çeşitli alternatifler arasından doğru seçimleri yapabilme, tasarruf ve tüketim dengesini kurabilme ve finansal piyasaları anlayabilme yeteneği olarak tanımlamak mümkündür. Finansal okuryazarlık kişilere bireysel, taşıt ve konut gibi kredi kullanımının hangi dönemlerde avantajlı olduğu, kredi kartı kullanımı, emeklilik planları ve sigorta gibi işlemlerin hangilerinin kişinin menfaatine uygun olduğunun kişi tarafindan anlaşılabilir olmasını sağlamaktadır. Bir kişinin finansal okuryazarlık düzeyinin yüksek olması risk-getiri dengesi kurmasına ve finansal piyasaları anlamasına pozitif katk1 sağlar. Bilhassa gençlerin ve üniversitede öğrenim gören öğrencilerin finansal okuryazarlık seviyesinin yüksek olması ülke geleceği için önemlilik arz etmektedir. Üniversitede öğrenim gören öğrencilerin finansal okuryazarlık bilgi seviyelerini artırmak yalnızca bölümlerde okutulan finans ve ekonomi dersler ile pek mümkün görünmemektedir. Bu kültürü kazandırabilmek ancak aile içerisindeki ebeveynlerin temel finans bilgilerinin yükseltilmesi ile desteklenmelidir.

Finansal piyasalarda yaşanan değişiklikler şahıslara çeşitli firsatlar sunmaktadır. Buna karşın artan finansal ürün ve hizmetlerin karmaşıklı̆̆ bireyleri finansal riskler ile karşı karşıya bırakmaktadır. Bireyin finansal gelişmeleri takip edip anlayabilmesi, finansal okuryazarlık düzeyinin geliştirilmesi ile mümkündür (Temizel ve Bayram, 2011: 77). Hogarth, Beverly ve Hilgert (2003) göre; finans bilgi düzeyi iyi, bankacılık ve sigortacılık, yatırım, para ve varlık yönetimi konularında bilgi sahibi olan bir kişi bilinçli bir finansal tüketicidir.

Literatürde finansal okuryazarlığın ölçülmesi için yapılan akademik çalışmalarda gerek üniversite öğrencileri üzerinde gerekse bireyler üzerinde çok farklı değişkenler kullanılmaktadır. Bu çalışmada Kahramanmaraş Sütçü İmam Üniversitesi Sosyal Bilimler Meslek Yüksekokulu (MYO) öğrencilerinin finansal okuryazarlık düzeylerinin ölçülmesi ve bu düzeylerin demografik değişkenlere göre farklılıklarının analiz edilmesi amaçlanmıştır.

\section{FINANSAL OKURYAZARLIK}

Finans kavramını "bireylerin ya da kurumların ihtiyaç duyduğu fonların sağlanması ve bunların etkili bir şekilde kullanılması" şeklinde tanımlamak mümkündür. İnsanların bu fonları etkili bir şekilde kullanmaları için yeterli bilgi ve beceriye sahip olmaları gerekmektedir. Finansal okuryazarlık kavramı bu noktadan hareketle ortaya çıkmıştır (Demir vd., 2016: 431). Bütçeleme, yatırım, 
tasarruf, sigorta, gelir-gider eşleşmesi gibi uygulamaları finansal okuryazarlık süreçlerine dahil etmek mümkündür. İlave olarak, müşterilerin finansal ürünhizmet ve kavramları hakkında bilgi ve yeteneklerini geliştirmeleri, finansal firsat ve riskleri daha iyi görmeleri gibi tüm faaliyetler finansal okuryazarlık süreçlerine dahildir (Temizel, 2010: 5-7).

Ekonomik İşbirliği ve Kalkınma Örgütü (OECD) finansal okuryazarlık kavramını, "tüketicilerin bilinçli kararlar almaları, yardıma ihtiyaç duyduklarında nereye başvurabileceklerini bilmeleri ve finansal refahlarını yükseltecek diğer eylemleri gerçekleştirmeleri için bilgi ve/veya objektif tavsiyeler yardımıyla yeteneklerini geliştirmesi süreci” olarak tanımlamaktadır (OECD, 2013:144). Türkiye Cumhuriyet Merkez Bankası (TCMB) ise finansal okuryazarlığı, "bireyin bütçesini yönetirken etkili ve bilinçli kararlar vermesini sağlayan finansal bilgiye sahip olması ve bu kararlar yoluyla kişisel finansal refahını artırma becerisidir" şeklinde tanımlamaktadır (TCMB, 2015: 5).

Finansal okuryazarlığa sahip insanlar, gündelik hayatında meydana gelen finansal sorunlara karşılık etkin çözüm yolları bulurken, diğer taraftan finans piyasaları da verimli ve etkili bir şekilde işleyebilecektir. Buradan hareketle finansal okuryazarlık insanlar açısından önemli olduğu kadar ülke ekonomisi ve finansal piyasalar açısından da önem arz etmektedir (Yücel, 2017:19).

İnsanların finansal okuryazarlık bilgi düzeyi, yatırım ve tasarruf etme konusunda alacağ 1 kararlarda ülkenin ekonomik gelişiminde önemli bir etkiye sahiptir. Sağlanan bu pozitif etkinin sürekliliği için bireylerin doğru bir şekilde yönlendirilmesi gerekmektedir. İnsanlar yatırım ve tasarruflarını doğru enstrümanlarla gerçekleştirip ülke ekonomilerine katkı sağlayacak şekilde yaparlarsa, bireysel açıdan olduğu kadar ülke ekonomileri açısından da pozitif gelişim sağlanmış olacaktır.

\subsection{Finansal Okuryazarlığın Önemi}

Finansal okuryazarlığın önemini Bianco ve diğerleri (2000) : “İyi bir finansal okuryazar olmanın önemi ile dünya dili olarak değerlendirilen İngilizce bilmenin önemini eş değer kabul etmek gerekir. Bu yüzden finansal okuryazarlığın iktisadi ve idari bilimler fakültelerinde ders olarak okutulmasının zamanı gelmiştir" diyerek vurgulamışlardır.

Finansal okuryazarlık kişilerin yetenekli birer yatırımcı olmasını sağlarken, aynı zamanda finansal becerilerini de geliştirmektedir (Langley, 2008:25). Bu durum tasarrufların etkin kullanımına pozitif katkı sağlarken diğer taraftan yatırım kararlarının da daha rasyonel hale gelmesine neden olmaktadır. Tasarruf kavramı ekonomi biliminde en önemli kavramların başında gelmektedir. Ekonomide, sermayenin temelini tasarruflar oluşturmaktadır. Yatırımlar ile 
tasarruflar arasındaki korelasyon düzeyi göz önüne alındığında, tasarruf bilinci ve birikimi, ekonomik büyüme ve yatırımlarla paralellik göstermektedir. Yani ekonomik büyüme yatırıma, yatırımlar ise tasarruflara bağlı olmaktadır (Çolak ve Öztürkler, 2012: 4). Ekonomideki "tasarruf-yatırım-büyüme" halkalarının oluşumu sağlayan ve bu faktörlerin verimliliğini artıran önemli unsurlardan bir tanesinin de bireylerin finansal okuryazarlık düzeyi olduğunu söylemek mümkündür.

Günümüzde finansal konularda eğitim almış bireylerin bile karmaşık finans dünyasında etkin kararlar alma konusunda zorlanmaları finansal okuryazarlı̆g 1 daha da önemli kılmaktadır. Başta Amerika Birleşik Devletleri olmak üzere, gelişmiş birçok ülkede bireylerin büyük bir kısmı yeterince tasarruf yapmamaktadırlar. Bu nedenle, dünya nüfusunun her geçen gün artması, doğal kaynaklarda yaşanan yetersizlikler, toplumlarda finansal okuryazarlık seviyelerini yükseltmek ve tasarruf bilincinin ivedi bir şekilde yayılmasını sağlamak, tüm dünya ülkelerinin ekonomik ve sosyal politikalarının en önemli gündem maddesi olarak karşımıza çıkmaktadır (Biçer ve Altan, 2016; 1504). Dolasıyla finansal okuryazarlığın, yaş, cinsiyet, statü ve sosyoekonomik ayrımlar olmaksızın tüm toplumları kapsaması, ülkelerin ekonomik refahlarının sağlanması bakımından oldukça önemlidir.

\section{LITERATÜR İNCELEMESİ}

Finansal okuryazarlık kavramı, finans literatüründe sağlam bir temele dayanarak yerini almaya başlamıştır. Türkiye'de finansal okuryazarlık alanında yapılan çalışmaların genelde son on yılı kapsadığı görülmektedir. Literatür taraması çalışmasında, dünyada ve Türkiye'de finansal okuryazarlık kavramının farklı yönlerden analiz edildiği araştırmalardan bazılarına özet olarak yer verilmiştir.

Ulusal ve uluslararası kuruluşlarca da üzerinde önemle durulan konulardan biri olan finansal okuryazarlık ile ilgili yapılan araştırmalarda farklı hedef kitleler baz alınmıştır. Brown ve arkadaşları (2006) işletmelere yönelik çalışma yürütürken, Atkinson ve Messy (2012), Bönte ve Filipiak (2012), Disney ve Gathergood (2013), Fettahoğlu (2015), Dağdelen (2017), ise hedef kitlesini hane halkı olarak belirlemiştir. Üniversite öğrencilerine yönelik yürütülen çalışmalara ise Chen ve Volpe (1998), Temizel ve Bayram (2011), Kılıç vd. (2015), Şamiloğlu vd. (2016), Elmas ve Y1lmaz (2016), Solomon vd (2018), Beal ve Delpachitra (2003), Cude vd. (2006), Alkaya ve Yağlı (2015), Sarıgül (2014), Bağc1 ve Arabac1 (2019), Y1lmaz ve Aslan (2020), Salman (2020) ve Tursun vd. (2020) örnek olarak verilebilir. 
Temizel ve Bayram (2010), öğrencilerin finansal durumlarını yönetmede kendilerini bulundukları seviyeden daha başarılı olduklarını tespit etmişlerdir. Finansal okuryazarlık seviyesinin arttırılmasını sağlayacak programların eğitim ve öğretim müfredatlarında yer alması gerektiğini, finansal okuryazarlık hususunda yaygın bir eğitim sunabilecek internet ve sosyal medya gibi araçların kullanılmasının daha faydalı olacağını belirtmişlerdir.

Kılıç, vd. (2015), üniversite öğrencilerinin finansal okuryazarlık düzeylerinin farklı demografik özellikleri açısından incelendiği çalışma sonucunda erkek öğrencilerin kadın öğrencilere göre finansal okuryazarlık düzeyinin daha yüksek olduğunu ortaya çıkarmışlardır. Ayrıca okuryazarlık düzeylerinde kredi kartı ve internet bankacılığ kullanımının etkili olduğu tespit edilmiştir. Öğrencilerin finansal okuryazarlık ile ilgili en çok bilgi sahibi oldukları hususun bireysel bankacılık konusu olduğu ve finansal okuryazarlık ile ilgili en az bilgiye sahip olduğu hususun ise yatırım konusu olduğu belirlenmiştir. Ayrıca bu çalışmanın sonucunda güncel finans bilgileri konusunda öğrencilerin daha fazla duyarlılığa sahip oldukları tespit edilmiştir.

Fettahoğlu (2015), hane halkının finansal okuryazarlık düzeylerinin belirlenmesine ve aile bütçesinin yönetimi hususunda bilgi ve davranışlarının nasıl olduğunu belirlemeye çalışmıştır. Araştırmanın sonucuna göre finansal okuryazarlık konusunda katılımcıların temel seviyede bilgilerinin olduğu ancak karmaşık ve bilgi gerektiren ürün, araç ve teknikler konusunda yetersizliklerinin olduğu tespit edilmiştir.

Yenilmez (2019), finansal okuryazarlık düzeyini, not ortalaması ve aylık hane halkı geliri değişkenlerinin belirgin bir şekilde etkilediği, fakat anne ve babanın eğitim düzeyinin belirgin bir etkisinin olmadığı ortaya konmuştur.

Salman ve Esmeray (2020), öğrencilerin kredi kartı kullanım durumuna göre finansal okuryazarlık düzeyleri arasında istatistiki olarak anlamlı bir farklılık olmadığı tespit edilmiştir. İnternet bankacıllğı kullanan öğrencilerin finansal okuryazarlık düzeyinin daha yüksek olduğunu tespit etmiş̧lerdir.

Tursun vd. (2020), finansal okuryazarlık düzeylerinin cinsiyet ve bölümlere göre farklılık göstermediği ancak öğrencilerin başarı notu ortalamalarına göre farklılık gösterdiği tespit edilmiştir. Yılmaz ve Aslan (2020) ise öğrencilerin yaşları ve öğrenim gördükleri sınıfları yükseldikçe finansal okuryazarlık düzeylerinin de arttı̆̆ 1 tespit etmiştir.

Uluslararası literatüre bakıldığında finansal okuryazarlık alanında yapılan çalışmalarda ulusal literatüre benzer bir yaklaşımın olduğu görülmektedir. Çalışmaların büyük çoğunluğu ele alınan örneklem grubunun ilk olarak finansal okuryazarlık düzeyini ortaya koymayı amaçlamıştır. 
Chen ve Volpe (1998), hedef kitlesinin üniversite öğrencilerinden oluştuğu çalışmalarında öğrencilerin finansal okuryazarlık seviyelerinin eğitim düzeyi, cinsiyet, yaş, iş deneyim gibi demografik özelliklerine göre farklılık gösterip göstermediğini tespit etmeye çalışmışlardır. Araştırma sonucunda öğrencilerin finansal okuryazarlık düzeylerinin söz konusu özelliklere göre farklılık gösterdiği, finansal okuryazarlık düzeylerinin yeterli düzeyde olmadığı ve bu yetersizliğin almış oldukları finans eğitiminin yetersizliğinden kaynaklandığı tespit edilmiştir.

Lusardi (2008), ABD'de bazı etnik gruplar üzerinde yaptığı çalışmasına göre cinsiyet bakımından kadınların ve uyruk bakımından Afrikalıların Amerikalılara göre eğitim seviyesinin daha düşük olduğunu ve bu kişilerin finansal okuryazarlık seviyelerinin de düşük olduğunu, hatta finansal cehaletin toplumun geneline yayıldığı tespit etmiştir.

Roij vd. (2011), bireylerin finansal okuryazarlığını ölçmek ve borsa katılımı ile ilişkisini inceledikleri çalışmasında, katılımcıların çoğunluğunun temel finansal bilgileri; "bileşik faiz, enflasyon ve paranın zaman değeri" kavramlarını bildiklerini tespit etmişlerdir.

Almenberg ve Söderbergh (2011) İsveç’te yaptıkları çalışmada, finansal okuryazarlık düzeyinin kadın, yaşlı, eğitim seviyesi ve gelir düzeyi düşük olanlarda düşük çıktığını ortaya koymuşlardır.

Rodrigues vd.(2012), öğrencilerin finansal birikimlerini yaparken ailelerinden öğrendikleri bilgilerin karar almada önemli bir etkiye sahip olduğu sonucuna varmıştır. Ayrıca çalışma, öğrencilerin yaşları ilerledikçe finansal okuryazarlık düzeylerinin de arttığını ortaya koymuştur.

Klapper ve Panos (2013), Rusya'da ekonomik kriz döneminde düşük seviyedeki finansal okuryazarlık düzeyinin etkilerini araştırmışlardır. Araştırma sonucunda borçlanma oranlarının ani bir şekilde yükseldiği ortamda hane halkının sadece \% 41 'nin bileşik faiz kavramını bildikleri sonucuna varmışlardır.

Dick ve Jaroszek (2013), Almanya'daki tüketici kredisi kullanımın belirleyicilerini araştırdıkları çalışmalarında kolay erişilebilen ancak nispeten daha masraflı olan tüketici kredisi kullanım sıklığının finansal okuryazarlıkla ters ilişki içinde olduğunu ortaya koymuşlardır. Ayrıca finansal eğitimin tüketici tercihlerini iyileştirmek için önemli bir rol oynadığını belirtmişlerdir.

Mahdzan ve Tabiani (2013), Malezya özelinde finansal okuryazarlığın tasarruf üzerindeki etkisini incelemişlerdir. Çalışmanın bulguları finansal okuryazarlık düzeyinin bireysel tasarruf üzerinde önemli ve olumlu bir etkisi 
olduğunu göstermektedir. Düzenli birikimin, cinsiyetin, gelir ve eğitim düzeyinin korunmasının tasarruf etme olasılığını olumlu yönde etkilediği sonucuna ulaşı1mıştır.

Duca ve Kumar (2014), ABD'de hane halkları üzerinde yaptıkları çalışmalarında konut kredi kullanımı ve finansal okuryazarlık arasındaki ilişkiyi araştırmışlardır. Araştırma sonuçlarına göre finansal okuryazarlık düzeyi düşük hanelerin konut kredisinden vazgeçtiklerini tespit etmişlerdir.

Ricci ve Caratelli (2017), finansal okuryazarlık, emeklilik planlaması ve finansal kurumlara duyulan güven arasındaki ilişkiyi 2010 y1lında İtalya hane halkı üzerine yaptıkları anket çalışması ile incelemişlerdir. Bulunan sonuçlara göre güvenin hem bireysel emeklilik kararlarında hem de kıdem tazminatını özel emeklilik sistemine ayırma üzerinde olumlu bir etkiye sahip olduğunu tespit etmişlerdir.

Solomon vd. (2018), öğrencilerin finansal okuryazarlık düzeyinin hem gelişmiş hem de gelişmekte olan ülkelerden çok düşük olmasından dolayı bu durumun halkların refahı üzerinde olumsuz etkisi olduğunu vurgulamışlardır. Çalışmada Botswana ülkesinde ortaokul düzeyindeki müfredat incelenmiştir. İnceleme sonucunda öğrencilere kişisel finansal okuryazarlık eğitiminin verilmesi gerekliliği tespit edilmiştir.

Kadoyo ve Khan (2019), Cinsiyet, yaş ve eğitim vb. demografik faktörlerin, gelir ve meslek vb. sosyo-ekonomik faktörlerin finansal okuryazarlık düzeyini önemli ölçüde etkilediği sonucuna varılmıştır.

\section{YÖNTEM}

Çalışmamızın bu bölümünde, Kahramanmaraş Sütçü İmam Üniversitesi Sosyal Bilimler (MYO) öğrenim gören öğrencilerin finansal okuryazarlık düzeylerinin belirlenmesi ve öğrencilerin yaş, cinsiyet, öğrenim gördüğü program, sınıf, internet bankacılığı, kredi kartı ve bireysel emeklilik sahiplik durumuna göre finansal okuryazarlık düzeylerinin tespitine ilişkin ilgili analizlerin yapılması için verilerin toplanma yöntemi ve bulgularına yer verilmiştir.

\subsection{Araştırmanın Amacı ve Örneklem}

Araştırmanın hedef kitlesi Kahramanmaraş Sütçü İmam Üniversitesi Sosyal Bilimler MYO'nda bulunan Bankacılık ve Sigortacılık, Büro Hizmetleri ve Sekreterlik, Pazarlama, İşletme Yönetimi, Halkla İlişkiler ve Tanıtım, Muhasebe ve Vergi Uygulamaları, Lojistik, Turizm ve Otel İşletmeciliği, Maliye ve Aşçılık 
bölümlerinden toplam 3.015 öğrenciden oluşmaktadır. Evren bilindiği için örneklem hesaplaması aşağıdaki şekilde yapılmıştır:

Örneklem hesaplanmasında $n=\frac{\mathrm{N} t^{2} p q}{d^{2}(\mathrm{~N}-1)+t^{2} p q}$ formülü kullanılmıştır (Karagöz 2014: 151). Formülde; n: örnek büyüklüğ̈̈nü, p: topluluk tahminini, d: kabul edilebilir tolerans düzeyini, Z: istenilen güven aralığını göstermektedir. $p$ parametresi bilinmediğinden, en yüksek değeri veren $(0,5 \times 0,5=0,25)$ değeri kullanılmıştır. Sosyal bilimlerde araştırmacılar tarafindan genel kabul görmüş güven aralığının $\% 95$ olmasından dolayı, $\mathrm{Z}$ değeri 1.96 olarak esas alındığında araştırmanın örneklem büyüklüğ̈̈ 341 olarak hesaplanmıştır. Araştırma kapsamında ankete katılan ve analiz edilebilir cevap veren 467 öğrencinin verileri değerlendirilmiştir.

\subsection{Veri Toplama ve Analiz Yöntemi}

$\mathrm{Bu}$ araştırmada veri toplama yöntemi olarak anket kullanılmıştır. Anket çalışması meslek yüksekokulu öğrencilerine online olarak yapılmıştır. Anket çalışması esnasında öğrencilere araştırmanın amacı ve ne için yapıldığı açıklanmıştır. Araştırmada, Kılıç, Ata ve Seyrek (2015) tarafından geliştirilen anket formu kullanılmıştır. Yazarlardan anketin kullanılabilmesi için izin alınmıştır. Anket çalışması, 7 bölüm ve toplam 38 sorudan oluşmaktadır. Çalışmamızda kullanmış olduğumuz anket ile meslek yüksekokulu öğrencilerinin finansal bilgilerini ölçmekten ziyade, onların finansal okuryazarlık seviyelerinin tespit edilmesi amaçlanmıştır. Öğrencilerin finansal okuryazarlık başarı düzeylerini tespit etmek için, ankette sorulara verdikleri doğru cevaplar için "1 puan”, yanlış verilen cevap ya da fikrim yok cevapları için "0 puan" verilmiştir. Ankete katılan her öğrenci maksimum 38 puan alabilmektedir. Araştırmada; her bir alt gruba ait öğrencilerin finansal okuryazarlık puanlarının yüzdeleri ile açıklayıcı değişkenler arasındaki ilişkinin istatistiksel olarak önemli olup olmadığı Bağımsız Örneklem T Testi ve Tek Yönlü Varyans Analizi ile kontrol edilmiştir. Tek Yönlü Varyans Analizi sonucunda F değeri anlamlı çıkan değişkenlerin gruplarına ilişkin puan yüzdeleri arasındaki farkın anlamlılı̆̆ Tukey Testi ile kontrol edilmiş ve sonuçlara ilişkin veriler tablolar halinde sunulmuştur.

\subsection{Araştırmanın Hipotezleri}

Araştırmanın amacı doğrultusunda geliştirilen hipotezler aşağıda belirtilmiştir:

"H1. Öğrencilerin cinsiyetleri ile finansal okuryazarlık düzeyleri arasinda anlamlı bir ilişki vardır." 
"H2. Öğrencilerin yaşları ile finansal okuryazarlık düzeyleri arasında anlamlı bir ilişki vardır".

"H3. Öğrencilerin öğrenim gördükleri bölüm ile finansal okuryazarlık düzeyleri arasında anlamlı bir ilişki vardır."

“H4. Öğrencilerin öğrenim gördükleri sınıf ile finansal okuryazarlık düzeyleri arasında anlamlı bir ilişki vardır."

"H5. Internet bankacıllğg kullanan ögrenciler ile kullanmayan ögrencilerin finansal okuryazarlık düzeyleri arasında anlamlı bir ilişki vardır."

"H6. Kredi kartı kullanan ögrenciler ile kullanmayan ögrenciler arasında finansal okuryazarlık düzeyleri arasında anlamlı bir ilişki vardır."

"H7. Bireysel emeklilik sitemine kayıtlı olan ögrenciler ile kayıtlı olmayan ögrrencilerin finansal okuryazarlık düzeyleri arasında anlamlı bir ilişki vardır.",

Finansal okuryazarlık düzeyi ile demografik özellikler arasındaki ilişkiye yönelik hipotezler için parametrik test yöntemleri arasında yer alan t testi ve Anova testi uygulanmıştır. Anova testi sonucunda gruplar arasında fark çıkması durumunda bu farkın hangi gruptan kaynaklandığını bulmak için post hoc testleri arasında yer alan Tukey testi uygulanmıştır. İstatistiksel yorumlamalar yapilırken, ankette yer olan sorulara verilen yanıtların tümü için frekans analizleri yapılarak yüzdelik dilimlerle ifade edilmiştir.

\subsection{Bulgular}

\subsubsection{Demografik Bulgular}

Araştırmaya katılın öğrencilerin cinsiyeti, yaşı, sınıfı, okuduğu bölümü, internet bankacılığı ve kredi kartı kullanım durumuna göre frekans ve yüzde analizi bilgileri aşağıdaki Tablo 1'de detaylı bir şekilde gösterilmiştir.

Tablo 1. Demografik Özellikler

\section{Demografikler}

Cinsiyet

$\begin{array}{ll} & \text { Toplam } \\ \text { Yaş } & \text { 18-21 } \\ & 22-24 \\ & 24 \text { ve Üzeri } \\ & \text { Toplam }\end{array}$

$\begin{array}{cc}\text { Frekans (n) } & \text { Yüzde (\%) } \\ 278 & 59,5 \\ 189 & 40,5 \\ 467 & 100 \\ 190 & 40,7 \\ 250 & 53,5 \\ 27 & 5,8 \\ 467 & 100\end{array}$




$\begin{array}{clcc} & \text { Bankacılık ve Sigortacılık } & 58 & 12,5 \\ & \text { Büro Hizmetleri ve } & 26 & 5,6 \\ & \text { Sekreterlik } & & \\ & \text { Pazarlama } & 14 & 2,6 \\ \text { Öğrencinin Okuduğu } & \text { Halkla Ilişkiler ve Tanıtım } & 55 & 11,8 \\ \text { Program } & \text { Muhasebe ve Vergi } & 56 & 12 \\ & \text { Uygulamaları } & & \\ & \text { İsletme Yönetimi } & 110 & 23,7 \\ & \text { Lojistik } & 47 & 10,1 \\ & \text { Turizm ve Otel İşletmeciliği } & 14 & 3 \\ & \text { Maliye } & 56 & 12 \\ & \text { Aş̧ıllk } & 31 & 6,7 \\ & \text { Toplam } & 467 & 100 \\ \text { Sinıf } & \text { 1.Sınıf } & 328 & 70,3 \\ & \text { 2.Sınıf } & 139 & 29,7 \\ \text { İnternet Bankacılığı } & \text { Toplam } & 467 & 100 \\ \text { Kullanma Durumu } & \text { Hayır } & 344 & 73,6 \\ & \text { Toplam } & 123 & 26,4 \\ \text { Kredi Kartı Kullanma } & \text { Evet } & 467 & 100 \\ \text { Durumu } & \text { Hayır } & 313 & 67 \\ & \text { Toplam } & 154 & 33 \\ \text { Bireysel Emekliliğe } & \text { Evet } & 467 & 100 \\ \text { Sahip Olma Durumu } & \text { Hayır } & 41 & 8,7 \\ & \text { Toplam } & 426 & 91,3 \\ & & 467 & 100\end{array}$

Araştırmaya katılanların 278'i (\%60) kadın, 189’u (\%40) erkek öğrencilerden oluşmaktadır. Erkek ve kadın dağılımı arasındaki farklara baktığımızda araştırma katılımcıları arasında cinsiyet açısından fark olduğu gözlemlenmektedir. Katılımcıların büyük bir kısmı 1.sınıf öğrencilerinden oluşmaktadır. Örneklemin büyük bir kısmı internet bankacılığını aktif olarak kullandığı görülmektedir. Ankete katılan öğrencilerin büyük bir çoğunluğunun bireysel emeklilik ürününe sahip olmadığ tespit edilmiştir.

\subsection{2. Öğrencilerin Demografik Özelliklerine Göre Başarı Puan Durumu}

Öğrenciler üzerine yapılan anket çalışması yedi bölümünden oluşmaktadır. İlk altı bölüm finansal okuryazarlık bilgi düzeylerini ölçmeye yönelik olan farklı kategorilerden oluşmakta son bölüm ise öğrenci profillerini ortaya çıarmak amacıyla birtakım demografik soruları içermektedir. Birinci bölümde yer alan sorular öğrencilerin genel ekonomi ve finans, ikinci bölüm bankacıllk, üçüncü bölüm emeklilik ve sigortacilık, dördüncü bölüm finansal tablolar, beşinci bölüm yatırım, altıncı bölüm vergi ve mevzuat ve yedinci bölüm de genel matematik ve faiz hesaplamaları konusundaki bilgilerini ölçmeyi amaçlamaktadır. 38 adete 
soruya verilen doğru cevaplar üzerinden ortalama başarı puanları hesaplanmıştır. Çalışmanın analiz bölümünde uygulanan tüm testlerde ortalama başarı puanları kullanılmıştır. Ankete katılan öğrencilerin demografik özelliklerine göre 100 üzerinden hesaplanmış ortalama başarı puanları aşağıda yer alan Tablo 3'te detaylı bir şekilde gösterilmiştir.

Tablo 2. Öğrencilerin Demografik Özelliklere Göre Ortalama Başarı Puan Durumu

\begin{tabular}{|c|c|c|c|c|c|c|c|c|c|}
\hline \multicolumn{10}{|c|}{ Ortalama Başarı Puanları (100 üzerinden) } \\
\hline & & TEB & BBB & ESB & FTB & YBP & VMB & MFB & GBP \\
\hline \multicolumn{10}{|l|}{ Genel } \\
\hline \multicolumn{10}{|l|}{ Başarı } \\
\hline Puanları & & 48 & 61 & 60 & 51 & 29 & 59 & 34 & 48 \\
\hline \multirow{2}{*}{ Cinsiyet } & Kadın & 45 & 59 & 59 & 55 & 33 & 55 & 33 & 48 \\
\hline & Erkek & 54 & 65 & 62 & 46 & 26 & 64 & 35 & 51 \\
\hline \multirow{15}{*}{ Bölüm } & Bank. ve & & & & & & & & \\
\hline & Sig. & 59 & 65 & 69 & 61 & 30 & 60 & 45 & 57 \\
\hline & Büro Hiz. & & & & & & & & \\
\hline & Sek. & 51 & 66 & 68 & 41 & 33 & 57 & 25 & 50 \\
\hline & Pazarlama & 49 & 50 & 62 & 46 & 37 & 50 & 25 & 46 \\
\hline & Halkla & & & & & & & & \\
\hline & İlişkiler & 45 & 55 & 61 & 42 & 23 & 48 & 28 & 44 \\
\hline & Muh..Vergi & & & & & & & & \\
\hline & Uyg & 50 & 61 & 58 & 56 & 31 & 70 & 39 & 52 \\
\hline & İşletme & & & & & & & & \\
\hline & Yönt. & 51 & 67 & 58 & 54 & 29 & 63 & 36 & 52 \\
\hline & Lojistik & 36 & 55 & 51 & 43 & 23 & 59 & 23 & 41 \\
\hline & Turizm & 43 & 46 & 50 & 52 & 19 & 40 & 17 & 39 \\
\hline & Maliye & 49 & 63 & 66 & 63 & 31 & 55 & 35 & 51 \\
\hline & Aşçılık & 38 & 60 & 60 & 38 & 30 & 59 & 37 & 46 \\
\hline \multirow{2}{*}{ Sinif } & 1. Sinif & 48 & 62 & 61 & 54 & 30 & 57 & 34 & 49 \\
\hline & 2. Sinif & 49 & 60 & 59 & 44 & 26 & 62 & 35 & 48 \\
\hline Bireysel & Evet & 48 & 63 & 59 & 48 & 26 & 62 & 27 & 48 \\
\hline Emeklilik & Hayır & 48 & 61 & 61 & 52 & 29 & 58 & 34 & 49 \\
\hline Kredi Kart1 & Evet & 51 & 67 & 64 & 48 & 31 & 63 & 38 & 52 \\
\hline Kullanımı & Hayır & 47 & 58 & 59 & 53 & 28 & 57 & 32 & 48 \\
\hline İnternet & Evet & 49 & 64 & 61 & 50 & 29 & 60 & 34 & 50 \\
\hline \multicolumn{10}{|l|}{ Bankacılı̆̆ } \\
\hline Kullanımı & Hayır & 47 & 55 & 59 & 54 & 28 & 54 & 33 & 47 \\
\hline \multicolumn{4}{|c|}{ TEB: Temel Ekonomi ve Finans Başarı Puanı } & \multicolumn{6}{|c|}{ BBB: Bireysel Bankacılık Başarı Puanı } \\
\hline \multicolumn{4}{|c|}{ ESB: Emeklilik ve Sigortacılık Başarı Puanı } & \multirow{2}{*}{\multicolumn{6}{|c|}{$\begin{array}{l}\text { FTB: Finansal Tablolar Başarı Puanı } \\
\text { VMB: Vergi ve Mevzuat Başarı Puanı }\end{array}$}} \\
\hline \multicolumn{4}{|c|}{ YBP: Yatırım Başarı Puanı } & & & & & & \\
\hline \multicolumn{4}{|c|}{ MFB: Matematik ve Faiz Hesaplamaları Puanı } & \multicolumn{6}{|c|}{ GBP: Genel Başarı Puanı } \\
\hline
\end{tabular}


Anket sonuçlarına göre öğrencilerin finansal okuryazarlık genel başarı düzeyi $\% 48$ olarak tespit edilmiştir. Anket sorularına verilen cevaplar incelendiğinde en yüksek başarı puanına bireysel bankacılık kategorisinde ulaşıldığı (\%61) görülürken, en düşük başarı puanın ise yatırım bankacılı̆̆ kategorisinde olduğu (\%29) görülmektedir.

Öğrencilerin cinsiyetine göre bakıldığında erkek öğrencilerin genel başarı puanının kadın öğrencilere göre daha yüksek olduğu görülmektedir. Finansal okuryazarlık düzeyi erkek öğrenciler için $\% 51$, kadın öğrenciler için ise $\% 48$ olarak gerçekleşmiştir.

Ankete katılım sağlayan öğrencilerin öğrenim gördükleri bölümlere göre başarı düzeylerine bakıldığında, Bankacılık ve Sigortacılık bölümü öğrencileri en yüksek (\%57), Turizm ve Otel İşletmeciliği öğrencileri en düşük (\%39) başarı puanına sahip olduğu görülmektedir. Sınıf kategorisine göre bakıldığında birinci sınıf öğrencilerin $\% 49$, ikinci sınıf öğrencilerinin ise $\% 48$ olarak başarı puanına sahip oldukları görülmektedir.

Öğrencilerin kredi kartı kullanım durumlarına göre genel başarı düzeyine bakıldığında, kredi kartı kullanan öğrencilerin (\%52) finansal okuryazarlık düzeyinin, kullanmayanlara (\%48) göre daha yüksek olduğu görülmektedir. Benzer durum internet bankacıllğg kullanım durumunda da geçerlidir. Başarı düzeyi bireysel emeklilik sistemine kayıtlı öğrencilerin \%48, olmayanların ise \%49 olarak gerçekleşmiş̧ir.

\subsubsection{Cinsiyet ile Finansal Okuryazarlık Düzeyleri Arasındaki İlişkinin İncelenmesi}

Ankete katılan Öğrenci gruplarının finansal okuryazarlık düzeyleri ile cinsiyetleri arasında istatistiksel olarak anlamlı bir ilişkinin olup olmadığ 1 Bağımsız Örneklem t Testi ile kontrol edilmiştir. Tablo 3'te test sonuçları gösterilmiştir.

Tablo 3. H1 Hipotezi t Testi Sonuçları

\begin{tabular}{|c|l|c|c|c|c|c|c|}
\hline Hipotez & Cinsiyet & $\mathbf{N}$ & $\overline{\mathbf{X}}$ & $\mathbf{s . s}$ & $\mathbf{t}$ & $\mathbf{p}^{*}$ & Hipotez Sonucu \\
\hline \multirow{2}{*}{ H1 } & Kadın & 278 & 48 & 1,11 & \multirow{2}{*}{$-2,16$} & \multirow{2}{*}{0,031} & KABUL \\
\cline { 2 - 5 } & Erkek & 189 & 51 & 1,42 & & & \\
\hline
\end{tabular}

$\mathrm{p}^{*}<0,05$ "N= Gözlem sayısı, s.s. $=$ Standart Sapma, $\mathrm{t}=$ Test İstatistiği $\overline{\mathrm{X}}=$ Aritmetik Ortalama, $\mathrm{p}=$ Anlamlılık Düzeyi”

T testi sonucuna göre, erkek öğrencilerle kadın öğrenciler arasında finansal okuryazarlık düzeyleri bakımından anlamlı bir fark olduğu tespit edilmiştir. 
Erkek öğrencilerin başarı düzeyi kadın öğrencilere göre daha yüksek çıkmıştır. $\mathrm{Bu}$ durumda "H1. Öğrencilerin cinsiyetleri ile finansal okuryazarlık düzeyleri arasında anlamlı bir ilişki vardır." hipotezi kabul edilmiştir.

\subsection{4. Öğrencilerin Yaşları ile Finansal Okuryazarlık Düzeyleri Arasındaki İliş̧ki}

Öğrencilerin yaşları ile finansal okuryazarlık seviyeleri arasında istatistiksel olarak anlamlı bir farklılığın olup olmadığı "Tek Yönlü Varyans Analizi (ANOVA)" analiz edilmiştir. Tablo 4 ve Tablo 5'de Tek Yönlü Varyans Analiz testinin sonuçları sunulmuştur.

Tablo 4. Yaş Değişkenine Göre Finansal Okuryazarlık Düzeylerine İlişkin Betimsel İstatistikler

\begin{tabular}{lccc}
\hline Yaşlar & $\mathbf{N}$ & $\overline{\mathbf{X}}$ & S.s \\
\hline $18-20$ & 190 & 46,64 & 20,21 \\
$20-22$ & 205 & 49,4 & 17,62 \\
$22-24$ & 45 & 53,35 & 19,77 \\
24 ve & & & \\
Üstü & 27 & 55,32 & 17,61 \\
\hline Toplam & $\mathbf{4 6 7}$ & $\mathbf{4 9 , 0 0}$ & $\mathbf{1 9 , 0 3}$ \\
\hline
\end{tabular}

"N= gözlem sayısı, $\overline{\mathrm{X}}=$ ortalama, s.s.= standart sapma"

Tablo 4'e göre öğrencilerin yaşları yükseldikçe finansal okuryazarlık düzeylerinin de yükseldiği görülmektedir. Öğrencilerin yaşları ile finansal okuryazarlık düzeyleri arasında paralellik tespit edilmiştir. Tek Yönlü Varyans Analizi testi ile yaş değişkenine göre ortaya çıkan bu farklılığının anlamlı olup olmadığı test edilmiştir. Analiz sonucu ortaya çıkan sonuçlar Tablo 5'de gösterilmiştir.

Tablo 5. H2 Hipotezi Tek Yönlü Varyans Analiz Testi Sonuçları

\begin{tabular}{lccccc}
\hline & Kareler Toplamı & df & Ortalama Kare & F & $\mathbf{p}^{*}$ \\
\hline Gruplar arası & 3021,771 & 3 & 1007,257 & 2,813 & 0,039 \\
Grup içi & 166127,693 & 464 & 358,034 & & \\
Toplam & 169149,464 & 467 & & & \\
“* $<<0,05, \mathrm{df}=$ serbestlik derecesi, $\mathrm{F}=$ test istatistiği, $\mathrm{p}=$ anlamlılık düzeyi” &
\end{tabular}

Tek Yönlü Varyans analiz test sonucuna göre ankete katılan öğrencilerin yaşları ile finansal okuryazarlık düzeyleri arasında anlamlı fark tespit edilmiştir $(\mathrm{F}=2,813, \mathrm{p}<0,05)$. Analiz sonucunda tespit edilen bu farklılı̆̆ın hangi sınıflar 
arasında olduğunu belirlemek için Post Hoc ikili karşılaştırmalardan Bonferroni testi uygulanmıştır. Bonferroni sonucuna göre, 24 ve üstü yaş grubuna ait finansal okuryazarlık düzeyinin 18-20 yaş grubundaki öğrencilere göre farkl1lık gösterdiği, bu farklılı̆̆ın istatistiksel olarak anlamlı düzeyde olduğu tespit edilmiştir. Bu durumda, "H2. Öğrencilerin yaşları ile finansal okuryazarlık düzeyleri arasında anlamlı bir ilişki vardır" hipotezi kısmi olarak kabul edilmiştir.

\subsection{5. Öğrenim Görülen Bölüm ile Finansal Okuryazarlık Düzeyleri Arasındaki İliş̧ki}

Ankete katılım sağlayan öğrencilerin okudukları bölüm ile finansal okuryazarlık düzeyleri arasında istatistiksel olarak anlamlı bir farklılığın olup olmadığı yine Tek Yönlü Varyans Analiz testi ile test edilmiştir. Test sonuçları Tablo 7'de gösterilmiştir.

Tablo 6. Öğrenim Görülen Bölüm ile Finansal Okuryazarlık Düzeyleri Arasındaki İlişkiye İlişkin Betimsel İstatistikler

\begin{tabular}{lccc}
\hline \multicolumn{1}{c}{ Bölümler } & $\mathbf{N}$ & $\overline{\mathbf{X}}$ & s.s. \\
\hline Büro Hizmetleri ve Sekreterlik & 26 & 45,82 & 22,38 \\
Pazarlama & 14 & 44,33 & 18,62 \\
Halkla İlişkiler ve Tanıtım & 55 & 45,74 & 19,04 \\
Muhasebe ve Vergi Uygulamaları & 56 & 49,50 & 21,14 \\
İşletme Yönetimi & 110 & 52,27 & 16,94 \\
Lojistik & 47 & 43,03 & 19,76 \\
Turizm ve Otel İşletmeciliği & 14 & 39,45 & 22,00 \\
Aşçılık & 31 & 47,34 & 12,72 \\
Bankacılık ve Sigortacılık & 58 & 54,23 & 19,48 \\
Maliye & 56 & 50,96 & 18,29 \\
\hline Total & $\mathbf{4 6 7}$ & $\mathbf{4 9 , 0 0}$ & $\mathbf{1 9 , 0 3}$ \\
\hline
\end{tabular}

"N= Gözlem Sayısı, $\bar{X}=$ ortalama, s.s.= Standart Sapma"

Tablo 6'ye göre, finansal okuryazarlık başarı puan ortalaması en yüksek olan bölümün Bankacılık ve Sigortacılık $(54,23)$ olduğu, başarı puan ortalaması en düşük bölümünün ise Turizm ve Otel İşletmeciliği $(39,45)$ olduğu görülmektedir. Öğrencilerin öğrenim gördüğü bölüm değişkenine göre ortaya çıkan bu farklılığın istatistiksel olarak anlamlı bir farklılık olup olmadığına ilişkin yapılan Tek Yönlü Varyans Analiz test sonuçları aşağıdaki tabloda gösterilmiştir. 
Tablo 7. H3 Hipotezi Tek Yönlü Varyans Analiz Testi Sonuçları

\begin{tabular}{lccccc}
\hline & Kareler Toplamı & df & Ortalama Kare & F & $\mathrm{p}^{*}$ \\
\hline Gruplar arası & 7186,922 & 9 & 798,547 & 2,258 & 0,018 \\
Grup içi & 161962,543 & 458 & 353,630 & & \\
Toplam & 169149,464 & 467 & & & \\
\hline “* $\mathrm{p}<0,05 \mathrm{df}=$ Serbestlik Derecesi, $\mathrm{F}=$ test istatistiği, $\mathrm{p}=$ anlamlılık düzeyi” &
\end{tabular}

Yapılan test sonucunda öğrencilerin öğrenim gördükleri bölüm ile finansal okuryazarlık düzeyleri arasında ortaya çıkan farklılığın istatistiksel olarak anlamlı olduğu tespit edilmiştir $(\mathrm{F}=2,258 \mathrm{p}<0,05) . \quad \mathrm{Bu}$ durumda, " $H 3$. Öğrencilerin ögrenim gördükleri bölüm ile finansal okuryazarlık düzeyleri arasında anlamlı bir ilişki vardır" hipotezi kabul edilmiştir.

\subsection{6. Öğrencilerin Öğrenim Gördüğü Sınıf ile Finansal Okuryazarlık İlişkisi}

Öğrencilerin okuduğu sınıf ile finansal okuryazarlık düzeyleri arasında bir farklılık olup olmadığını tespit etmek için Bağımsız Örneklem t Testi ile kontrol edilmiştir. $t$ testi sonuçları Tablo 8.'de gösterilmiştir. Bağımsız Örneklem $t$ testi sonuçlarına göre öğrencilerin öğrenim gördükleri sınıf ile finansal başarı düzeyleri arasında istatistiksel olarak anlamlı bir farklılığın olmadığı sonucuna varılmıştır.

Tablo 8. H4 Hipotezi t Testi Sonuçları

\begin{tabular}{cccccccc}
\hline Hipotez & $\begin{array}{c}\text { Öğrencinin } \\
\text { Okuduğu Sınıf }\end{array}$ & $\mathbf{N}$ & $\overline{\mathbf{X}}$ & s.s & $\mathbf{t}$ & $\mathbf{p}^{*}$ & Hipotez Sonucu \\
\hline \multirow{2}{*}{$\mathrm{H} 4$} & 1.Sınıf & 328 & 49 & 18,9 & 0,49 & 0,63 & RED \\
& 2.Sınıf & 139 & 48 & 19,38 & & &
\end{tabular}

“*p<0,05, N= Gözlem Sayıs1, s.s.= Standart Sapma, $\mathrm{t}=$ Test İstatistiği $\overline{\mathrm{X}}=$ Aritmetik Ortalama, $\mathrm{p}=$ Anlamlılık Düzeyi”

Tablo 8 incelendiğinde birinci sınıfta öğrenin gören öğrencilerin finansal okuryazarlık düzeyleri ikinci sınıfta okuyanlara göre daha yüksek ortalamaya sahip olmalarına rağmen bu farklılığın istatistiki olarak anlamlı olmadığ ( $>>0,05)$ tespit edilmiştir. Bu durumda, "H4. Öğrencilerin öğrenim gördükleri sinıf ile finansal okuryazarlık düzeyleri arasında anlamlı bir ilişki vardır" hipotezi reddedilmiştir. 


\subsection{7. Öğrencilerin İnternet Bankacılığı Kullanmaları ile Finansal Okuryazarlık Düzeyleri Arasındaki İlişskinin İncelenmesi}

Öğrencilerin finansal okuryazarlık başarı düzeyleri ile internet bankacılığı kullanmaları arasında anlamlı bir ilişkinin olup olmadığı "Bağımsız Örneklem t Testi” ile kontrol edilmiştir. Tablo 9' da testin sonuçları gösterilmiştir.

Tablo 9. H5 Hipotezi t Testi Sonuçları

\begin{tabular}{cccccccc}
\hline Hipotez & $\begin{array}{c}\text { İnternet Bankacılı̆̆ } \\
\text { Kullanım Durumu }\end{array}$ & $\mathbf{N}$ & $\overline{\mathbf{X}}$ & s.s & $\mathbf{t}$ & $\mathbf{p}^{*}$ & Hipotez Sonucu \\
\hline \multirow{2}{*}{ H5 } & Evet & 346 & 50 & 19,21 & \multirow{2}{*}{1,47} & \multirow{2}{*}{0,63} & RED \\
& Hayır & 121 & 47 & 18,4 & & & \\
\hline
\end{tabular}

“* $\mathrm{p}<0,05, \mathrm{~N}=$ Gözlem Sayısı, s.s. $=$ Standart Sapma, $\mathrm{t}=$ Test İstatistiği $\overline{\mathrm{X}}=$ Aritmetik Ortalama, $\mathrm{p}=$ Anlamlılık Düzeyi”

Tablo 9 incelendiğinde internet bankacıllğg kullanan öğrencilerin ortalama başarı puanları kullanmayan öğrencilere göre daha yüksek çıkmıştır. Ancak bu farklılık istatistiksel açıdan anlamlı görülmemektedir $(\mathrm{p}>0,05)$. Bu durumda, "H7. Internet bankacilı̆̆ kullanan öğrenciler ile kullanmayan ögrencilerin finansal okuryazarlı düzeyleri arasında anlamlı bir ilişki vardır" hipotezi reddedilmiştir.

\subsection{8. Öğrencilerin Kredi Kartı Kullanım Durumu İle Finansal Okuryazarlık Düzeyleri Arasındaki İlişkinin İncelenmesi}

Öğrencilerin finansal okuryazarlık düzeyleri ile kredi kartı kullanım durumları arasında anlamlı bir ilişkinin olup olmadığı Bağımsız Örneklem t Testi ile kontrol edilmiştir. Tablo 10'da testin sonuçları gösterilmiştir.

Tablo 10. H6 t Testi Sonuçları

\begin{tabular}{cccccccc}
\hline Hipotez & $\begin{array}{c}\text { Kredi Kart } \\
\text { Kullanım Durumu }\end{array}$ & $\mathbf{N}$ & $\overline{\mathbf{X}}$ & s.s & $\mathbf{t}$ & $\mathbf{p}^{*}$ & Hipotez Sonucu \\
\hline \multirow{2}{*}{ H6 } & Evet & 154 & 52 & 19,04 & 2,09 & 0,83 & RED \\
& Hayır & 313 & 48 & 18,92 & & & \\
\hline
\end{tabular}

“* $\overline{\mathrm{p}}<0,05 \mathrm{~N}=$ Gözlem Sayıs1, s.s.= Standart Sapma, $\mathrm{t}=$ Test İstatistiği $\overline{\mathrm{X}}=$ Aritmetik Ortalama, $\mathrm{p}=$ Anlamlılık Düzeyi”

Tablo 10'a göre kredi kartı kullanan öğrencilerin ortalama başarı puanlarının kredi kartı kullanmayan öğrencilere göre daha yüksek olmasına rağmen bu farklılığın istatistiksel açıdan anlamlı olmadığ $(\mathrm{p}>0,05)$ görülmektedir. $\mathrm{Bu}$ durumda, "H6. Kredi Kartı Kullanan ögrenciler ile kullanmayan ögrencilerin 
finansal okuryazarlık düzeyleri arasında anlamlı bir ilişki vardır” hipotezi reddedilmiştir.

\subsection{9. Öğrencilerin Bireysel Emeklilik Sistemine Kayıtlı Olmaları ile Finansal Okuryazarlık Düzeyleri Arasındaki İlişkinin İncelenmesi}

Öğrencilerin bireysel emeklilik sistemine kayıtlı olmaları ile finansal okuryazarlık düzeyleri arasında anlamlı bir ilişkinin olup olmadığı Bağımsız Örneklem t Testi ile kontrol edilmiştir. Tablo 11'de testin sonuçları gösterilmiştir.

Tablo 11. H7 Hipotezi t Testi Sonuçları

\begin{tabular}{ccrrrrrr}
\hline Hipotez & $\begin{array}{c}\text { Bireysel Emeklilik } \\
\text { Durumu }\end{array}$ & \multicolumn{1}{c}{$\mathbf{N}$} & $\overline{\mathbf{X}}$ & s.s & $\mathbf{t}$ & $\mathbf{p}^{*}$ & Hipotez Sonucu \\
\hline \multirow{2}{*}{ H7 } & Evet & 41 & 48 & 21,32 & $-0,2$ & 0,25 & RED \\
& Hayır & 426 & 49 & 18,8 & & & \\
\hline
\end{tabular}

“* $<0,05 \mathrm{~N}=$ Gözlem Sayıs1, s.s.= Standart Sapma, $\mathrm{t}=$ Test İstatistiği $\overline{\mathrm{X}}=$ Aritmetik

Ortalama, $\mathrm{p}=$ Anlamlılık Düzeyi”

Tablo 11'e göre, bireysel emeklilik ürününe sahip olmayan öğrencilerin başarı ortalamaları bireysel emeklilik sistemine kayıtlı olan ögrencilere göre daha yüksek çıkmıştır. Ancak bu farklılık istatistiksel açıdan anlamlı görülmemektedir ( $>00,05)$. Bu durumda, "H7. Bireysel emeklilik sistemine kayltl ögrenciler ile kayıtlı olmayan ögrencilerin finansal okuryazarlı düzeyleri arasında anlamlı bir ilişki vardır" hipotezi reddedilmiştir.

\section{SONUÇ VE TARTIŞMA}

Bireylerin tasarrufları artırma, yatırım ve borç yönetimi gibi konularda sağlıklı finansal kararlar alabilmeleri için finansal okuryazarlık düzeylerinin geliştirilmesi oldukça önemlidir. Bununla birlikte, son yıllarda hızla artan finansal krizler, finansal dolandırıcılıklar ve gittikçe yaygınlaşan dijital finansal ürün ve hizmetler, ülkelerin finansal okuryazarlık düzeylerini belirleme ve artırma ihtiyaçlarını daha da ön plana çıkartmıştır. Bu amaçla, bütün dünyada finansal okuryazarlık ile ilgili araştırmalar hız kazanmış ve bu çalışmalar sonucunda finansal okuryazarlığın optimal seviyeye çıkartılması ve yaygınlaştırılması için birçok stratejiler geliştirilmiştir. Bu bağlamda, özellikle kariyerlerinin başında olan ve iş hayatına yeni girecek olan üniversite öğrencilerinin gelirlerini ve tasarruflarını daha iyi yönetmesi, finansal piyasalara katılım sağlayabilmesi için finansal okuryazarlığın önemini çok iyi kavraması ve finans konularında sağlıklı eğitimler almaları gerekmektedir (Tetik, 2019: 2769). 
$\mathrm{Bu}$ araştırmada, öğrencilerin finansal okuryazarlık düzeyinin belirlenmesi ve finansal okuryazarlığın öğrencilerin demografik özellikleri ile ilişkili olup olmadığı tespit edilmeye çalışılmıştır. Bu amaçla, Kahramanmaraş Sütçü İmam Üniversitesi, Sosyal Bilimler MYO'da öğrenim gören 467 öğrenciye anket çalışması uygulanmış ve elde edilen veriler üzerinde analizler yapılmıştır. Öğrencilerin genel finansal okuryazarlık düzeyleri ile alt bileşenleri olan; "temel ekonomi ve finans, bireysel bankacilık, emeklilik ve sigortacilık, finansal tablolar, yatırım, vergi ve mevzuat" alanlarında başarı düzeyleri belirlenmiştir. Araştırmada öğrencilerin demografik özelliklerine göre finansal okuryazarlık düzeylerinin farklılık gösterip göstermediği test edilmiştir. Araştırma kapsamında elde edilen verilere, bağımsız örneklem " $t$ testi ve Tek Yönlü Varyans Analiz Testi” uygulanmıştır.

Çalışmada elde edilen bulgulara göre; Kahramanmaraş Sütçü İmam Üniversitesi Sosyal Bilimler MYO'da öğrenim gören öğrencilerin finansal okuryazarlık düzeylerinin düşük olduğunu göstermiştir. Diğer benzer araştırmalardan (örn. Chen ve Volpe, 2002; Barmaki, 2015; Kılıç vd., 2015; Danışman vd., 2016; Dilek vd., 2016) elde edilen bulguların sonuçlarına yakın ortalamalara ve benzer sonuçlara ulaşıldığ ve bu anlamda literatürün desteklendiği söylenebilir. Ancak çalışmamızın örneklemini iki yıllık yüksekokul öğrencileri oluşturmaktadır. Yukarıda örnek gösterilen literatürdeki benzer araştırmalarda ise fakülte öğrencileri üzerinde yapılmıştır.

Öğrencilerin finansal okuryazarlık düzeyleri ile ilgili olarak en başarılı oldukları alanın bireysel bankacılık, en başarısız oldukları alanın ise yatırım olduğu görülmüştür. Özellikle yatırım alanında düzeyin düşüklüğü literatürdeki birçok çalışmada da benzer şekilde tespit edilmiştir (Örn: Yılmaz ve Aslan, 2020, Kılıç vd, 2015, Klapper ve Panos, 2013).

Erkek öğrencilerin finansal okuryazarlık başarı düzeyinin kadın öğrencilere göre daha yüksek düzeyde olduğu ortaya çıkmıştır. Araştırmada elde edilen bu sonuç literatürdeki birçok çalışma ile de tutarlılık göstermektedir (Chen ve Volpe, 1998: 114; Chen ve Volpe, 2002: 294; Worthington, 2006: 73; Furtuna 2007: 20; Dvorak ve Hanley, 2010: 650, K1lı̧ ve Diğerleri, 2015, 143, Yılmaz ve Aslan, 2020, 196). Öğrencilerin öğrenim gördükleri bölümlere göre finansal okuryazarlık düzeyleri arasında farklılık gözlemlenmiştir.

En yüksek finansal okuryazarlık düzeyine sahip bölüm Bankacılık ve Sigortacılık, en düşük finansal okuryazarlık düzeyine sahip bölüm ise Turizm ve Otel İşletmeciliği bölümüdür. Bu durum doğal olarak Bankacılık ve Sigortacılık bölümü öğrencilerinin finans konusunda almış oldukları derslerin finansal okuryazarlık derslerine olumlu etkisinden kaynaklanmaktadır. Öğrencilerin 
yaşları ile finansal okuryazarlık başarı düzeyleri arasında istatistiksel olarak anlamlı bir sonuç ortaya çıkmıştır.

Öğrencilerin yaşları arttıkça finansal okuryazarlık başarı düzeyleri de artmaktadır. Diğer taraftan öğrencilerin okumuş oldukları sınıf ile finansal okuryazarlık arasında istatistiksel olarak anlamlı bir farklılık bulunmadığı tespit edilmiştir. Çalışmada öğrencilerin bireysel emeklilik sistemine dâhil olup olmadığına, internet bankacılığı ve kredi kartı kullanıp kullanmama durumuna göre finansal okuryazarlık düzeylerinde istatistiksel olarak anlamlı bir farklılık tespit edilememiştir. Ancak kredi kartı ve internet bankacıllğı kullanan öğrencilerin finansal okuryazarlık başarı puanları diğer kullanmayan öğrencilere göre daha yüksek çıkmıştır.

Bu bulgular çerçevesinde, öğrencilerin genel anlamda teori ve uygulamalar ile ilgili sahasında uzman kişilerden sağlıklı ve güncel finansal eğitim almaları son derece önemli ve gereklidir. Bu eğitimlerle öğrenciler finansal kavramları doğru bir şekilde öğrenerek piyasalardaki gelişmeleri değerlendirip rasyonel olarak yorumlayabilecek seviyeye gelebilecektir. Kılıç vd. (2015)'in de belirttiği gibi Finansal okuryazarlık sadece üniversite öğrencilerini ilgilendiren bir konu olmayıp, bireylerin emeklilik yaşamlarını dahi etkilediğinden tüm toplumun bilgi sahibi olması gereken bir alandır. Bu nedenle finansal okuryazarlığ geliştirmek için eğitim programlarına bu alanla ilgili seçmeli dersler eklenebilir, alanında uzman kişiler tarafindan seminerler verilebilir ve bireylerin piyasalar hakkında bilgilerini artırıcı simülasyon eğitimler düzenlenebilir. Finansal piyasalar hakkında öğrencilerin bilgilerini artırıcı seçmeli ders ve eğitim seminerlerinin verilmesi finansal okuryazarlığın gelişmesine pozitif katkı sağlayacaktır.

\section{KAYNAKÇA}

Bağcı, H., ve Arabacı, S.M (2019). Mali okuryazarlık düzeyinin ve finansal okuryazarlığ 1 etkileyen faktörlerin belirlenmesi. Issletme ve Yönetim Çalışmalart: Uluslararası Bir Dergi,7(3), 6888. https://doi.org/10.15295/bmij.v7i3.1232.

Barmaki, N. (2015). Üniversite öğrencilerinin finansal okuryazarlık düzeylerini belirlemeye yönelik bir araştırma: Hacettepe Üniversitesi örneği. [Yayınlanmamış Doktora Tezi], Hacettepe Üniversitesi.

Bianco, C., Bosco, A. and Susan, M. (2000), Financial Literacy: What Are Business Schools Teaching, Bristol Gabelli School of Business Roger Williams University, 8, 24-27. 
Biçer, E. B. ve Altan, F. (2016). Üniversite öğrencilerinin finansal okuryazarlık ile ilgili tutum ve davranışlarının değerlendirilmesi. Atatürk Üniversitesi Sosyal Bilimler Enstitüsü Dergisi, 20 (4), 1501-1517.

Braunstein, S. ve Welch, C. (2002). Financial literacy: An overview of practice, research, and policy. Federal Reserve Bulletin, 2002-2.

Chen, H. and Volpe, R.P. (1998). An analysis of personal finance literacy among college students. Financial Services Review, 7(2), 107-128.

Chen, H. and Volpe, R.P. (2002). Gender differences in personal financial literacy among college students. Financial Services Review, 11, August, 289-307.

Cole, S., Paulson, A. and Shastry, G.K. (2012). Smart money: The affect of education on financial behavior. Harward Busineess School Working Paper, 2012-April, No: 09-071, 3-48. https://doi.org/10.1093/rfs/hhu012.

Çolak, Ö. F. ve Öztürkler, H. (2012). Tasarrufun belirleyicileri: küresel tasarruf eğiliminde değişim ve türkiye'de hane halkı tasarruf eğiliminin analizi. Bankacılar Dergisi, 82, 3-44.

Danışman, E., Sezer, D. ve Gümüş, U. T. (2016). finansal okuryazarlık düzeyinin belirlenmesi: Üniversite öğrencileri üzerine bir araştırma. Kara Harp Okulu Bilim Dergisi, 26(2), 1-37.

Demir. G., Cihangir, M. ve Şak, N. (2016). Demografik özelliklerin finansal okuryazarlık üzerine etkisinin multinominal logit model ile incelenmesi. Akademik Sosyal Araştırmalar Dergisi, 4(25), 430-438.

Dick, C. D. and Jaroszek, L. M. (2013). Knowing what not to do: Financial literacy and consumer credit choices. https://www.fdic.gov/news/conferences/consumersymposium/2013/Paper s /Jaroszek.pdf (19.07.2017)

Dilek, S., Küçük, O. ve Eleren, A. (2016). Kastamonu Üniversitesi öğrencilerinin ekonomi okuryazarlı̆̆ı, Insan ve Toplum Bilimleri Araşstırmaları Dergisi, $5(7)$.

Dilek, S., Keskingöz, H. ve Nergiz, E. (2019). Ekonomi okuryazarlığının girişimcilik niyeti üzerine etkisi. Üçüncü Sektör Sosyal Ekonomi Dergisi, 54(1), 89-107. 
Duca, J. and Kumar, A. (2014). Financial literacy and morgage equity withdrawals, Journal of Urban Economics, 80, 62-75

Dvorak, T. and Hanley, H. (2010). Financial literacy and the design of retirement plans. The Journal of Socio-Economics, 39, 645-652.

Elmas, B. ve Yılmaz, H. (2016). Finansal okuryazarlık: Ağrı İbrahim Çeçen Üniversitesi iktisadi ve idari bilimler fakültesi öğrencileri üzerine bir çalışma. Ă̆rı İbrahim Çeçen Üniversitesi Sosyal Bilimler Enstitüsü Dergisi, 2(1)

Fettahoğlu, S. (2015). Hane halkının finans eğitimi ve finansal okuryazarlık düzeyleri üzerine Kocaeli'nde bir araştırma. Muhasebe Finansman Dergisi, 14 (122), 101-106.

Furtuna, F. (2007). College students' personal financial literacy: Economic impact and public policy implications. Undergraduate Economic Review, 4(1). 1- 32

Gale, W.G. and Levine, R. (2011, October). Financial lLiteracy: What works? How could it be more effective? SSRN Electronic Journal (Şubat 2011). Erișim adresi: https://papers.ssrn.com/sol3/papers.cfm?abstract_id=2316933. http://dx.doi.org/10.2139/ssrn.2316933.

Hogart, J., Beverly, S.G and Hilgert, M. (2003). Patterns of financial behaviors: Implications for community educators and policy makers. Discussion, https://www.federalreserve.gov/communityaffairs/national/CA_Conf_Sus CommDev/pdf/ hogarthjeanne.pdf, 01.01.2021.

Karagöz, Yalçın (2014). SPSS 21,1 uygulamalı biyoistatistik, 1. Bask1 Nobel Yayınevi.

Kılıç, Y., Ata, H.A., ve Seyrek, İ.H. (2015), Finansal okuryazarlık: Üniversite öğrencilerine yönelik bir araştırma, Muhasebe ve Finansman Dergisi, Nisan 2015, 129

Klapper, L. and Panos G. (2013). Financial literacy and retirement planning: the Russian case. Journal of Pension Economics and Finance, 40 (4), 599-618.

Langley, P. (2008). The everyday life of global finance: Saving and borrowing in angloamerica. OUP Oxford.

Lusardi, A. (2008). Financial literacy: An essential tool for informed consumer choice?. NBER Working Paper, No. 14084, 1-29. 
Mahdzan, N. S. and Tabiani, S. (2013). The impact of financial literacy on individual saving: An exploratory study in the Malaysian context. transformations in Business \& Economics. 12(1), 41-55.

Oktay, M. ve Göker, İ.E. (2020). Finansal okuryazarlık düzeyinin bireylerin tasarruf eğilimi üzerindeki etkisi: Kırıkkale Üniversitesi akademik ve idari personeli üzerine bir araştırma. İşletme Akademi Dergisi, 2020, 1 (1): 3455 DOI: $10.26677 /$ TR1010.2020.350.

Salman, Ü.N. ve Esmeray, A. (2020). Finansal Okuryazarlı: Muhasebe ve Finansman Eğitimi Alan Öğrencilere Yönelik Bir Araştırma. Issletme Araştırmaları Dergisi Journal Of Busıness Research-Turk 2020, 12(2), 2002-2016 https://doi.org/10.20491/isarder.2020.958

Sohn, S., Joo, S. Grable, J.E., Lee, S. and Kim, M. (2012). Adolescents' financial literacy: The role of financial socialization agents, financial experiences, and money attitudes in shaping financial literacy among South Korean Youth. Journal of Adolescence, 35, 969-980.

Temizel, F. \& Bayram, F. (2011). Finansal okuryazarlı: Anadolu Üniversitesi iktisadi ve idari bilimler fakültesi (iibf) öğrencilerine yönelik bir araştırma. Cumhuriyet Üniversitesi İktisadi ve İdari Bilimler Dergisi, 12(1), 73-86.

Temizel, F. (2010). Mavi yakalılarda finansal okuryazarlık. Beta Basım Yayım Dağıtım.

Tetik, N. (2019). Üniversite öğrencilerinin finansal okuryazarlık düzeylerinin incelenmesi: İnönü Üniversitesi örneği Manas Sosyal Araştırmalar Dergisi, 8(3), 2755-2774.

Tursun, M., İkvan, A. ve Ukav, İ. (2020). Finansal yönetim eğitimi alan öğrencilerin algı ve finansal okuryazarlık düzeyleri üzerine bir araştırma. Bartın Üniversitesi İktisadi ve İdari Bilimler Fakültesi Dergisi, 2020, 11(22).

Türkiye Cumhuriyeti Merkez Bankası (2015). Aylı bülten. http://www.tcmb.gov.tr/wps/wcm/connect/TCMB+TR/TCMB+TR/Mai

$\mathrm{n}+$ Menu/Yayinlar/TCMB+Bulten/TCMB+Bulten, Erişim Tarihi: 01.02.2021

Widdowson, D. and Hailwood, K. (2007). Financial literacy and its role in promoting a sound financial system. Bulletin Reserve Bank of New Zeeland, 70(2), 37-47. 
Worthington, A.C. (2006). Predicting financial literacy in Australia. Financial Services Review, 15, 59-79.

Yenilmez, B. (2019). İşletme bölümü son sınıf öğrencilerin finansal okuryazarlık düzeyi (Ankara-Hacı Bayram Veli-Hacettepe Üniversitesi Örneği). Fırat Üniversitesi IIIBF Uluslararast İktisadi ve İdari Bilimler Dergisi, 3(2).

Yılmaz E. ve Aslan, T. (2020), Finansal okuryazarlık ve Siirt Üniversitesi öğrencilerine yönelik bir araştırma. Muhasebe ve Finansman Dergisi, Temmuz 2020, 181

Yücel, S. (2017). Üniversite öğrencilerinin finansal okuryazarlıklarının kredi kartı kullanım alışkanlıkları üzerine etkisinin incelenmesi: Bilecik Şeyh Edebali Üniversitesi- Hacettepe Üniversitesi Örneği. Yüksek Lisans Tezi, Bilecik Șeyh Edebali Üniversitesi.

* Bu araştırmanın anket formları uygulanmadan önce, Kahramanmaraş Sütçü İmam Üniversitesi Sosyal ve Beşerî Bilimler Etik Kurul Başvuru Formu doldurulmuş ve Etik Kurul İzni (KSÜ Sosyal ve Beşeri Bilimler Etik Kurulundan 16.04.2021-26790) alınmıştır. Anket, gönüllü olarak çalışmaya katılan ve çalışma grubunda yer alan öğrencilere açık uçlu görüşme formu ile yapılmıştır. 